\title{
MANFAAT DAN KEMUDAHAN YANG DIRASAKAN TERHADAP NIAT MENGGUNAKAN GO PAY PADA GENERASI Y DI SURABAYA
}

\author{
Sabila Salsabil ${ }^{1}$, Christina Sudyasjayanti ${ }^{2}$ \\ ${ }^{1}$ International Business Management, Universitas Ciputra Surabaya \\ ${ }^{2}$ International Business Management, Universitas Ciputra Surabaya \\ E-mail: christina.sudyasjayanti@ciputra.ac.id \\ E-mail:ssalsabil@student.ciputra.ac.id
}

Masuk : 18-06-2020, revisi: 02-07-2020, diterima untuk diterbitkan :02-07-2020

\begin{abstract}
ABSTRAK
Teknologi yang berkembang semakin canggih memberikan dampak yang baik dalam kehidupan, salah satunya pada bidang ekonomi. Contoh kemudahan yang ditimbulkan dalam bidang ekonomi adalah transformasi sistem pembayaran, saat ini pembayaran menggunakan uang tunai dirasa kurang efisien sehingga beberapa masyarakat mulai beralih dengan menggunakan pembayaran non tunai. Penelitian ini bertujuan untuk mengetahui pengaruh antara perceived usefulness terhadap behavior intention to use, perceived ease of use terhadap behavior intention to use, dan usia terhadap perceived usefulness dan perceived ease of use. Responden dalam penelitian ini berjumlah 150 orang pengguna layanan Go-Pay di Kota Surabaya yang termasuk dalam kategori Generasi Y. Hasil penelitian menunjukan bahwa perceived usefulness dan perceived ease of use berpengaruh terhadap behavior intention to use dan hanya usia 20-24 dan 35-40 yang terpengaruh oleh perceived usefulness dan perceived ease of use terhadap behavior intention to use.
\end{abstract}

Kata Kunci: perceived usefulness, perceived ease of use, behavior intention to use, dan TAM

\begin{abstract}
The development of technology impacted on economical sectors. One example of the convenience posed in the economic field is the transformation of the payment system, currently payments using cash are considered to be less efficient so some people have begun to switch to using non-cash payments. This research is aimed to determine the effect of perceived usefulness towards behavior intention to use, perceided ease of use towards behavior intention to use, and age on perceived usefulness and perceived ease of use. There are 150 users of Go-Pay services in Surabaya that included to $Y$ generation. This research showed that the variables perceived usefulness and perceived ease of use significantly affected behavior intention to use and only 20-24 and 30-34 years old that affected by perceived usefulness and perceived ease of use toward behavior intention to use.
\end{abstract}

Keywords: : perceived usefulness, perceived ease of use, behavior intention to use, and TAM

\section{PENDAHULUAN \\ Latar Belakang}

Kemajuan teknologi saat ini, semakin berkembang pesat dan berdampak pada berbagai sektor kehidupan, salah satunya pada bidang ekonomi. Contoh kemudahan yang ditimbulkan dalam bidang ekonomi adalah transformasi sistem pembayaran. Pembayaran dengan uang tunai atau cash baru-baru ini dianggap tidak lagi efisen, oleh karena itu masyarakat mulai berbondongbondong beralih menggunakan pembayaran non tunai (Pratami, 2018). Selain itu, meurut Widyanto et al (2020) maraknya penggunaan mobile payment disebabkan oleh ketertarikan konsumen untuk menggunakan gadget mereka untuk melakukan transaksi pembayaran produk atau layanan jasa dengan mulus. Hal ini dapat disebut sebagai bentuk transaksi elektronik apabila dilihat dari proses pembayaran dengan menggunakan media elektronik dan tanpa melibatkan pembayaran fisik sama sekali. Transaksi pembayaran elektronik dapat dilakukan dengan beberapa metode seperti: kartu debit; kartu kredit; mobile banking; internet banking; E-Wallet dan banyak media lainnya. 
Salah satu alat pembayaran non tunai yang akrab di masyarakat adalah E-money yang pertama kali diizinkan untuk digunakan sebagai alat pembayaran pada tahun 2009 oleh Bank Indonesia. Dikutip dari kompas.com 25 April 2019, Gubernur Bank Indonesia Perry Warjiyo melaporkan pertumbuhan penggunaan e-money yang sangat signifikan. Pada Bulan Februari 2019 penggunaan e-money meningkat sebanyak $77,6 \%$. Berita ini didukung dengan data survei yang diperoleh Asosiasi Penyelenggara Jasa Internet Indonesia (APJII) tentang penetrasi pengguna internet di Indonesia yang mencapai 64,8\% atau 171 juta dari 264 juta jiwa .

Survei yang dilakukan katadata.co.id menunjukan bahwa E-Wallet yang paling banyak digunakan pada tahun 2019 adalah Go-Pay. Melalui survei yang dilakukan oleh katadata.co.id manfaat paling banyak yang dirasakan para pengguna mengenai penggunaan dompet digital atau E-Wallet adalah karena mudah digunakan dan menghemat waktu. Menurut Anjelina (2018), Bank Indonesia sudah menetapkan Gerakan Nasional Non Tunai (GNNT) yang telah mulai dilakukan sejak 14 Agustus 2014 lalu. Gerakan yang ditetapkan oleh BI ini bertujuan untuk meningkatkan kesadaran masyarakat terhadap penggunaan alat pembayaran non tunai sehingga lambat laun akan memunculkan gerakan Less Cash Society.

Peran usia dalam penelitian ini berfokus pada persepsi penggunaan teknologi. Penelitian ini menyelidiki persepsi perbedaan penggunaan sistem aplikasi pada generasi Y yang lahir pada tahun 1980 hingga tahun 2000. Menurut Subari dan Ascarya dalam Pratami (2018) penggunaan alat pembayaran dipengaruhi oleh latar belakang masyarakat sesuai wilayahnya. Masyarakat yang tinggal kota kecil lebih menyukai transaksi dengan menggunakan pembayaran tunai, berbeda dengan masyarakat yang tinggal di kota besar.

\section{TAM (Technology Acceptance Model)}

Salah satu teori yang digunakan untuk melihat dampak penerimaan penggunaan sistem informasi adalah technology of acceptance model atau TAM, seperti dikatakan (Yani et al, 2018). Berdasarkan penelitian Widodo et al (2018) TAM memiliki 4 variabel yaitu, perceived usefullness (PU), perceived ease of use (PEOU), attitude toward using (ATU) dan behavior intention to use (BITU). Akan tetapi, berdasarkan penelitian sebelumnya oleh Suki dalam Widodo et al (2018) yang mendapati hasil bahwa hanya 3 variabel saja yang digunakan yaitu, PU, PEOU, dan BITU. Variabel ATU tidak digunakan dalam tersebut karena diketahui bahwa hubungan antara ATU dengan PU, PEOU, dan BITU sangat lemah. Sehingga, dalam penelitian ini yang digunakan ahanya 3 variabel saja yaitu PU, PEOU, dan BITU.

Perceived Usefulness (PU) merupakan suatu tingkat kepercayaan dimana penggunaan teknologi dengan sistem informasi mampu meningkatkan kinerja dan prestasi kerja penggunanya (Venkatesh et al, 2003). Perceived Usefulness pada mobile payment merujuk pada keuntungan yang didapatkan seperti misalnya, sejauh mana kesederhanaan dan kenyamanan dalam melakukan pembayaran Bailey et al., (2017). (Venkatesh et al, 2003) menyatakan Perceived Ease of Use (PEOU) merupakan tingkat kepercayaan pengguna terhadap sistem informasi yang dapat meringankan usaha untuk melakukan suatu pekerjaan. Davis dalam Anjelina (2018) menjelaskan definisi PEOU dengan menyatakan bahwa dengan menggunakan aplikasi mobile payment pengguna akan bebas dari usaha. Bailey et al (2017) menjelaskan Behavior Intention to Use (BITU) adalah kecenderungan dari perilaku untuk tetap menggunakan sebuah sistem informasi (Chao, 2019). Didukung oleh Yani et al (2018) behavior intention to use adalah suatu minat untuk melakukan sebuah perilaku. 
Pada penelitian ini ditambahkan variabel usia sebagai salah satu karakteristiknya karena ingin mengetahui perilaku Generasi Y dalam menggunakan Go-Pay. Hal ini sejalan dengan penelitian Pratami (2018) tentang pengaruh persepsi, sosial-demografi dan keuangan terhadap masyarakat dalam menggunakan pembayaran non tunai. Berraies et al (2017) melakukan penelitian tentang identifikasi efek pada aplikasi mobile banking pada pelanggan berdasarkan perbandingan antar generasi diantaranya baby boome, generasi X, dan generasi Y. Keterkaitan dengan penelitian ini adalah adanya kesamaan variabel dalam penelitian yaitu, $P U, P E O U$ terhadap BITU. Bailey et al (2017) melakukan penelitian tentang pembayaran berbasis seluler yang dilakukan oleh konsumen di Amerika Serikat menggunakan teori TAM.

\section{Rumusan Masalah}

\section{Pengaruh PU terhadap BITU}

Syahril dan Rikumahu (2018) dalam penelitiannya yang berfokus pada faktor-faktor yang mempengaruhi minat untuk menggunakan e-money di kalangan mahasiswa Universitas Telkom. Dalam penelitian tersebut didapatkan hasil bahwa perceived usefulness berpengaruh positif dan signifikan terhadap behavior intention to use. Temuan ini didukung oleh Pratami (2018) yang menyatakan bahwa perceived usefulness berpengaruh positif dan signifikan terhadap behavior intention to use.

H1 : PU berpengaruh terhadap BITU pada pengguna Go-Pay di Surabaya.

\section{Pengaruh PEOU terhadap BITU}

Yani et al (2018) mendapatkan hasil bahwa perceived ease of use berpengaruh terhadap Behavior Intention of Use. Sebab penelitian ini mendapati bahwa dengan adanya aplikasi yang mudah untuk digunakan maka penerimaan dalam masyarakat juga akan lebih mudah.

H2 : PEOU berpengaruh terhadap BITU pada pengguna Go-Pay di Surabaya.

\section{Pengaruh Usia, PU, dan PEOU terhadap BITU}

Jeffries dan Hunte dalam Bamforth dan Geursen (2017) menyatakan bahwa setiap generasi memiliki sikap dan pandangannya sendiri mengenai dunia yang dipengaruhi oleh keadaan sosial dan masa lalu sehingga membuat setiap generasi memiliki persepsi yang berbeda-beda. Pratami (2018) juga mengemukakan bahwa apabila usia seseorang semakin tua maka semakin rendah persepsinya untuk menggunakan layanan aplikasi.

H3: Usia berpengaruh pada hubungan PU dan PEOU terhadap BITU pada pengguna Go-Pay di Surabaya.

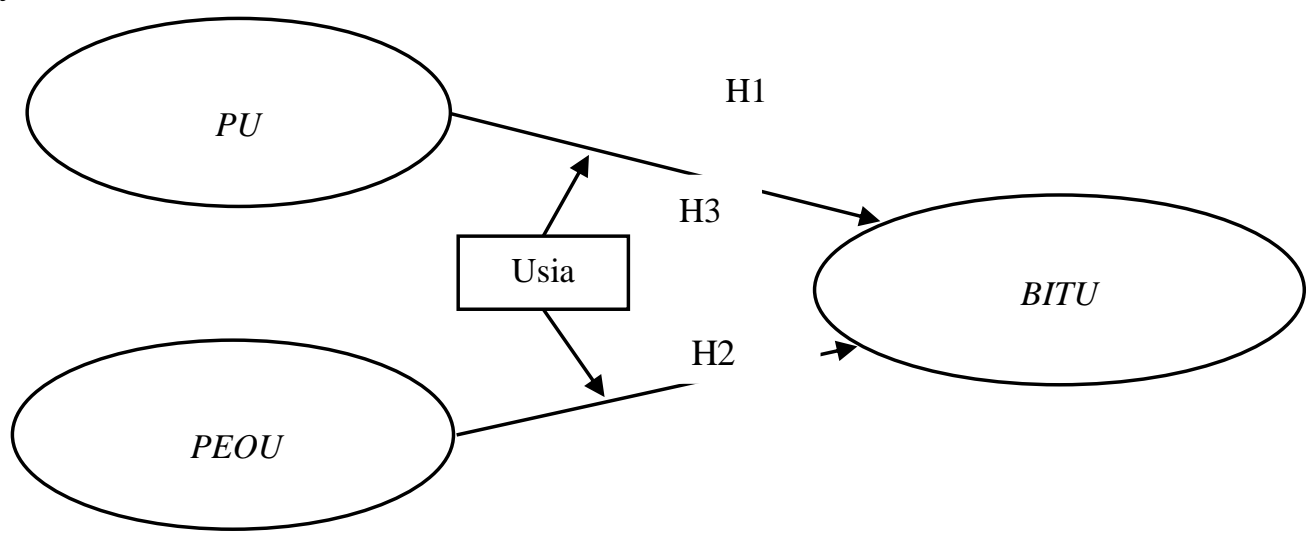

Gambar 1. Model Penelitian

Sumber: Peneliti 


\section{METODE PENELITIAN}

Penelitian ini menggunakan teknik pengambilan sample purposive sampling. Berikut adalah kriteria yang digunakan untuk sampel penelitian ini:

1. Tinggal di Surabaya

2. Usia antara 20 tahun hingga 40 tahun

3. Pengguna Go-Pay minimal 6 bulan

Berdasarkan hasil perhitungan dengan Rumus Lemeshow diketahui bahwa jumlah minimal sampel adalah 150 responden.

\section{Sumber Data dan Skala Pengukuran}

Penelitian ini menggunakan sumber data primer, seperti dikatakan Sugiyono dalam Syahril dan Rikumahu (2018) data primer merupakan data yang dikumpulkan pertama kali oleh peneliti seperti kuisioner. Skala likert 5 poin digunakan dalam penelitian ini, yaitu: (1) STS (sangat tidak setuju); (2) TS (tidak setuju); (3) CS (cukup setuju); (4) S (setuju); dan (5) SS (sangat setuju).

\section{Variabel dan Definisi Operasional}

Menurut Leon (2018) dan Bailey (2017) PU diukur dalam 4 indikator, (1) kemanfaatan, (2) peningkatan produktivitas, (3) kenyamanan, dan (4) memingkatkan efektivitas kerja. Leon (2018) mengindikasikan bahwa PEOU diukur dalam 3 indikator, (1) mudah digunakan, (2) mudah dipelajari, dan (3) tidak membutuhkan banyak usaha untuk dimengerti. Sedangkan BITU menurut Leon (2018) dan Bailey (2017) diukur melalui 4 indikator yaitu, (1) berlanjut di masa yang akan datang, (2) keinginan untuk selalu menggunakan, (3) selalu mencoba menggunakan, dan (4) keinginan untuk menggunakan sehari-hari. Berdasarkan survei yang dilakukan oleh APJII usia pengguna internet aktif di klasifikasikan dalam 4 kategori, yaitu (1) usia 20-24 tahun sebanyak 88\%, (2) usia 25-29 tahun sebanyak 83\%, (3) usia 30-34 tahun sebayak 76\%, dan (4) usia 35-40 tahun sebayak 68\%.

\section{Metode Analisis Data}

Metode analisis dalam penelitian ini dilakukan dengan: uji validitas dilihat dari nilai signifikansi (2 tailed) dan uji reliabilitas dilihat dari angka Cronbach's Alpha, uji asumsi klasik yang terdiri dari: uji normalitas; uji heteroskedastisitas; dan uji multikolinieritas, analisis regresi linear berganda, uji variabel dummy, uji $F$, uji t, dan uji koefisien determinasi $\left(\mathrm{R}_{2}\right)$.

\section{HASIL DAN PEMBAHASAN}

\section{Uji Validitas dan Reliabilitas}

Seluruh pernyataan variabel pada penelitian ini memiliki tingkat signifikansi $<0,05$ maka seluruh jawaban pernyataan dikatakan valid. Tabel 3.1 menunjukkan bahwa seluruh indikator dalam instrument penelitian ini dikatakan valid, sebab didapati bahwa tingkat signifikansinya lebih rendah dari 0,05. Instrumen dikatakan reliabel apabila nilai Cronbach's Alpha lebih besar dari 0,6. Pada Tabel 3.1 didapati bahwa dalam penelitian ini Cronbach Alpha seluruh variabel > 0,6 artinya instrumen dalam kuesioner dikatakan reliabel.

Tabel 3.1. Hasil Uji Validitas \& Reliabilitas

\begin{tabular}{|c|c|c|c|}
\hline \multirow[b]{2}{*}{ Variabel } & \multirow[b]{2}{*}{ Item } & \multicolumn{2}{|c|}{ Hasil } \\
\hline & & $\begin{array}{c}\text { Cronbach's } \\
\text { Alpha }\end{array}$ & Sig \\
\hline \multirow{4}{*}{$P U(\mathrm{X} 1)$} & $\mathrm{X} 1.1$ & \multirow{4}{*}{0,839} & 0,000 \\
\hline & $\mathrm{X} 1.2$ & & 0,000 \\
\hline & $\mathrm{X} 1.3$ & & 0,000 \\
\hline & X1.4 & & 0,000 \\
\hline
\end{tabular}




\begin{tabular}{|c|c|c|c|}
\hline & $\mathrm{X} 1.5$ & & 0,001 \\
\hline & X1.6 & & 0,000 \\
\hline \multirow{3}{*}{ PEOU (X2) } & $\mathrm{X} 2.1$ & \multirow{3}{*}{0,878} & 0,000 \\
\hline & X2.2 & & 0,000 \\
\hline & $\mathrm{X} 2.3$ & & 0,000 \\
\hline \multirow{4}{*}{ BITU (Y) } & Y.1 & \multirow{4}{*}{0,884} & 0,000 \\
\hline & Y.2 & & 0,000 \\
\hline & Y.3 & & 0,000 \\
\hline & Y.4 & & 0,000 \\
\hline
\end{tabular}

\section{Uji Asumsi Klasik}

Pada uji normalitas dilihat dari angka Klomogorov Smirnov dikatakan bahwa bila nilai signifikansinya > 0,05 maka persebaran data dinyatakan normal atau sebaliknya. Hasil pada Tabel 3.2 menunjukkan bahwa nilai signifikansi >0,05 yaitu sebesar 0,200 maka dapat dikatakan persebaran data dalam penelitian ini normal.

\begin{tabular}{|cc}
\multicolumn{2}{c}{ Tabel 3.2. Hasil Uji Normalitas } \\
\hline Keterangan & $\begin{array}{c}\text { Unstandarized } \\
\text { Residual }\end{array}$ \\
\hline Test Statistic & 0,060 \\
\hline Asymp.Sig.(2-tailed) & 0,200 \\
\hline
\end{tabular}

Uji asumsi klasik yang selanjutnya adalah uji heteroskedesitas, pengujian ini dilihat dari taraf signifikansi kedua variabel independen harus $>0,05$. Artinya, dalam penelitian ini tidak terjadi heteroskedastisitas. Sedangkan uji multikolineritas untuk menguji apakah ada korelasi antara variabel bebas dalam model regresi (Pratami, 2018). Pada hasil pengujian ini dapat diketahui bahwa nilai tolerance $>0,1$ dan nilai VIF $<10$ maka dapat dikatakan dalam penelitian ini tidak terjadi multikolinieritas antar variabel independen.

Tabel 3.3. Hasil Uji Heteroskedesitad dan Multikolinieritas

\begin{tabular}{ccc}
\hline Variabel & Sig. (2-tailed) & VIF \\
\hline PU (X1) & 0,422 & 2,122 \\
\hline PEOU (X2) & 0,452 & 2,122 \\
\hline
\end{tabular}

\section{Uji Hipotesis}

Hipotesis dalam penelitian ini diuji dengan regresi linier berganda. Selain itu, uji hipotesis juga dilakukan dengan uji F, uji t, dan uji variable dummy.

\section{Ui Regresi Linier Berganda}

Berdasarkan Tabel 3.4 diketahui nilai konstanta $(\alpha)$ sebesar 1,465 maka nilai prediksi variabel dependennya sebesar 1,465. Nilai koefisien regresi pada variabel PU adalaha 0,391. Nilai koefisien regresi pada variabel PEOU didapati 0,417. Maka dapar dikatakan bahwa apabila terjadi peningkatan pada PU dan PEOU akan meningkatkan BITU pengguna Go Pay. Pada uji T (T test) nilai signifikansi kedua variabel independen adalah 0,000 atau lebih kecil dari 0,05. Maka PU dan PEOU berpengaruh terhadap BITU Go Pay secara parsial.

$$
\mathrm{Y}=1,465+0,391 \mathrm{X}_{1}+0,417 \mathrm{X}_{2}
$$


Tabel 3.4. Hasil Regresi Linear Berganda dan Uji T

\begin{tabular}{|c|c|c|c|}
\hline \multirow{2}{*}{ Variabel } & \multirow{2}{*}{$\begin{array}{l}\text { Unstandardized } \\
\text { Coefficient B }\end{array}$} & \multicolumn{2}{|c|}{ T Test } \\
\hline & & $\mathbf{t}$ & t tabel \\
\hline Konstanta $(\alpha)$ & 1,465 & & \\
\hline $\mathrm{PU}(\mathrm{X} 1)$ & 0,391 & 8,028 & 1,65508 \\
\hline PEOU (X2) & 0,417 & 4,720 & 1,65508 \\
\hline
\end{tabular}

\section{Uji Koefisien Korelasidan Koefisien Determinasi}

Diketahui nilai signifikasnsi pada Uji $\mathrm{F}$ adalah 0,000 atau lebih kecil dari 0,05 , maka disimpulkan bahwa model regresi dapat digunakan untuk memprediksi variabel dependen dan dapat dikatakan bahwa variabel PU dan PEOU secara simultan berpengaruh terhadap BITU Go Pay. Pada uji koefisien determinasi, nilai $\mathrm{R}$ adalah 0,820 mendekati 1 . Artinya hubungan variabel independen dan variabel dependen terbilang kuat. Sedangkan nilai $\mathrm{R}^{2}$ diketahui sebesar 0,672 yang artinya variabel independen dalam penelitian ini mampu menjelaskan sebesar 67,2\% sedangkan 32,8\% lainnya yang tidak dijelaskan dalam penelitian ini.

\begin{tabular}{cccccc}
\multicolumn{5}{c}{ Tabel 3.5 Hasil Uji F \& Koefisien Determinasi } \\
Model & F & F Tabel & Sig. & $\mathbf{R}$ & $\mathbf{R}^{\mathbf{2}}$ \\
\hline Regresi & 150,506 & 3,06 & 0,000 & 0,820 & 0,672
\end{tabular}

\section{Uji Variabel Dummy}

Uji ini dilakukan untuk melihat apakah variabel usia berpengaruh pada hubungan PU ke BITU dan PEOU ke BITU. Uji variabel usia ini dilakukan per kategori usia, sebab peneliti ingin melihat lebih dalam karakteristik setiap kategori usia pada BITU Go Pay. Uji variable dummy dapat dilihat dari nilai signifikansinya, apabila nilai signifikansinya $<0,05$ maka kategori usia tersebut berpengaruh. Hasil pengujian menunjukkan bahwa hanya kategori usia 20-24 tahun dan 35-40 tahun yang berpengaruh. Dengan kata lain kategori usia, PU dan PEOU mempengaruhi niat mereka untuk menggunakan Go Pay. Sementara pada responden usia lainnya, PU dan PEOU tidak mempengaruhi BITU GoPay.

\begin{tabular}{rccc} 
Tabel 3.6. Hasil Uji Moderasi Variabel Usia \\
\cline { 2 - 3 } Usia & $\begin{array}{c}\mathbf{R} \\
\text { Square }\end{array}$ & $\begin{array}{c}\text { Unstandardized } \\
\text { Coefficients }\end{array}$ & \multirow{2}{*}{ Sig. } \\
\cline { 3 - 4 } & & $\mathbf{B}$ & \\
\hline $\mathbf{2 0 - 2 4}$ th & 0,682 & $-0,671$ & 0,036 \\
\hline $\mathbf{2 5 - 2 9}$ th & 0,672 & $-0,050$ & 0,895 \\
\hline $\mathbf{3 0 - 3 4}$ th & 0,672 & 0,087 & 0,814 \\
\hline $\mathbf{3 5 - 4 0}$ th & 0,693 & 1,481 & 0,002 \\
\hline
\end{tabular}

\section{Pembahasan}

Hasil penelitian ini menunjukan terdapat hubungan yang signifikan antara PU terhadap BITU. Hal ini terbukti karena nilai t hitung dari variabel PU adalah 8,028 sedangkan nilai t tabelnya sebesar 1,65508. Artinya, sebagaimana kriteria jika t hitung > dari t tabel maka hipotesis dapat diterima atau variabel perceived usefulness berpengaruh signifikan terhadap BITU. Hasil temuan ini didukung penelitian yang dilakukan oleh Pratami (2018) menyatakan bahwa preferensi dalam menggunakan alat pembayaran non tunai dipengaruhi oleh PU. Selain itu Syahril dan Rikumahu (2019) juga menyatakan bahwa kemudahan penggunaan mempengaruhi secara positif signifikan 
terhadap minat dalam menggunakan e-money. Dari indikator PU diketahui bahwa konsumen pengguna Go-Pay percaya bahwa dengan menggunakan Go-Pay memungkinkan membayar lebih cepat, memudahkan transaksi pembayaran, dan memudahkan dalam memeriksa pembayaran. Karena itu bisa disimpulkan bahwa semakin tinggi PU yang diberikan oleh aplikasi Go-Pay akan meningkatkan BITU penggunanya, dengan begitu dapat dikatakan H1 diterima.

Pada penelitian ini didapatkan hasil bahwa terjadi hubungan yang signifikan antara PEOU terhadap BITU. Hal ini dibuktikan dengan hasil nilai t hitung dari variabel PEOU adalah 4,720 sedangkan nilai t tabelnya sebesar 1,65508. Artinya, sebagaimana kriteria yang sudah ditetapkan jika t hitung $>$ dari t tabel maka PEOU berpengaruh signifikan terhadap BITU. Hasil dari penelitian ini didukung oleh pernyataan Prakosa dan Wintaka (2020) bahwa variabel perceived ease of use berpengaruh terhadap minat menggunakan ulang Go-Pay, artinya minat menggunakan Go Pay akan semakin tinggi apabila PEOU semakin tinggi juga. Selain itu Mandariza et al (2019) menyatakan bahwa PEOU merupakan salah satu unsur yang mempengaruhi konsumen terhadap penggunaan pembayaran electronic cash. Dilihat dari indikator PEOU menunjukkan bahwa konsumen pengguna Go-Pay percaya bahwa menggunakan Go-Pay tidak memerlukan upaya yang besar, mudah dalam memahami cara penggunaan Go-Pay, dan mudah dalam penggunaanya. Karena itu bisa disimpulkan bila PEOU yang diberikan oleh aplikasi Go-Pay meningkat maka akan meningkatkan BITU penggunanya, dengan begitu maka $\mathrm{H} 2$ dalam penelitian ini diterima.

Menurut Kumar dan Lim dalam Berraies et al (2017) Generasi Y merupakan generasi yang mencintai ponsel dan generasi awal yang dapat menerima perubahan teknologi khususnya layanan seluler. Hal ini dikarenakan Generasi $\mathrm{Y}$ dilahirkan dan tumbuh bersama dengan perkembangan teknologi ini. Berdasarkan hasil pengujian variabel usia, diketahui bahwa usia 2024 tahun dan 35-40 tahun berpengaruh pada BITU Go-Pay. Selain itu menurut Dhanapal et al dalam Berraies (2017) Generasi Y banyak memanfaatkan teknologi baik untuk pembelian online maupun mengambil keuntungan. Hal ini dikarenakan Generasi Y dilahirkan dan tumbuh bersama dengan perkembangan teknologi. Menurut Kim dan Hwang dalam Berraies et al (2017) menekankan bahwa pengguna ponsel yang berusia lebih muda cenderung menggunakan dalam hal hedonis, sedangkan pengguna yang lebih tua menggunakan ponsel untuk sesuatu yang bermanfaat.

Berdasarkan hasil pengujian variabel dummy diketahui bahwa hasil penelitian pada usia 20-24 tahun berpengaruh lebih rendah terhadap perceived usefulness dan perceived ease of use. Hal ini disebabkan karena menurut Chahal dan Rani dalam Florenthal (2018) mengungkapkan bahwa anak muda yang menggunakan sistem aplikasi cenderung dipengaruhi oleh teman-teman dan rekannya. Artinya, penggunaan sistem aplikasi pada anak muda bukan berdasarkan manfaatnya melainkan karena pengaruh teman-teman atau rekannya. Chong et al dalam Anjelina (2018) juga mengemukakan hal yang sama bahwa kelompok sosial baik keluarga maupun teman mempengaruhi keputusan penggunaan teknologi, semakin banyak teman atau keluarga yang menggunakan sebuah aplikasi maka akan mendorong pengguna untuk melakukan hal yang sama.

Hasil penelitian pada usia 25-29 tahun dan 30-34 tahun ditemukan tidak berpengaruh terhadap PU dan PEOU, artinya perceived usefulness dan perceived ease of use tidak mempengaruhi behavior intention to use Go-Pay pada konsumen di Surabaya. Karena untuk menciptakan nilai bagi konsumen perusahaan perlu memenuhi kebutuhan yang dibutuhkan oleh konsumen (Florenthal, 2018). Berdasarkan survei yang dilakukan oleh katadata.co.id pada tahun 2019 terdapat 4 macam $E$-Wallet yang paling banyak digunakan di Indonesia yaitu Go-Pay, OVO, 
DANA, dan LinkAja. Artinya, pengguna Go-Pay usia 25-29 tahun dan 30-34 tahun memiliki preferensi yang berbeda dalam menggunakan E-Wallet melihat tidak hanya Go-Pay satu-satunya media pembayaran elektronik yang banyak digunakan di Indonesia. Hasil penelitian pada usia 35-40 tahun ditemukan adanya pengaruh antara PU dan PEOU. Hal ini sejalan dengan penelitian yang dilakukan oleh Kim dan Hwang dalam Berraies et al (2017) yang menyatakan bahwa pada dasarnya usia yang lebih tinggi cenderung menggunakan ponsel untuk hal yang bermanfaat.

\section{Implikasi Manajerial}

Implikasi dari penelitian ini menunjukan bahwa semakin mudah penggunaan sistem aplikasi pembayaran berbasis teknologi maka akan semakin mudah pula diterima oleh masyarakat. Menurut Kim dan Hwang dalam Berraies et al (2017) mengatakan bahwa Generasi Y adalah generasi yang dalam kehidupan sehari-hari pengguna teknologi yang luas. Selain itu Generasi Y juga merupakan generasi yang tumbuh bersama dengan perkembangan teknologi. Tetapi pada hasil penelitian ini ditemukan bahwa hanya usia 20-24 tahun dan 35-40 tahun yang berpengaruh terhadap PU dan PEOU. Oleh karena itu dapat disimpulkan bahwa tidak semua yang termasuk dalam Generasi Y mampu menerima perubahan inovasi teknologi.

\section{KESIMPULAN DAN SARAN}

Berdasarkan penelitian yang sudah dilakukan, maka kesimpulan dalam penelitian ini adalah:

1. Perceived usefulness berpengaruh terhadap behavior intention to use

2. Perceived ease of use berpengaruh terhadap behavior intention to use

3. Perceived usefuleness dan perceived ease of use hanya berpengaruh pada kategori usia 20-24 dan $35-40$

Pada penelitian selanjutnya variabel lain yang tidak digunakan dalam penelitian ini diharapkan dapat ditambahkan, sehingga dapat menemukan indikasi lain yang dapat mempengaruhi konsumen dalam menggunakan layanan pembayaran berbasis teknologi. Pada penelitian selanjutnya bisa ditambahkan variabel lain seperti, perceived risk, perceived trust, social image, influence, fitur layanan, compatibily, subjective norm, dan perceived cost.

\section{REFERENSI}

Anjelina, A. (2018). Persepsi Konsumen Pada Penggunaan E-Money. Journal of Applied Managerial Accounting, 2(2), 219-231. https://doi.org/10.30871/jama.v2i2.934

APJII. (2019). Penetrasi \& Profil Perilaku Pengguna Internet Indonesia Tahun 2018. Apjii, 51. www.apjii.or.id

Bailey, A. A., Pentina, I., Mishra, A. S., \& Ben Mimoun, M. S. (2017). Mobile payments adoption by US consumers: an extended TAM. International Journal of Retail and Distribution Management, 45(6), 626-640. https://doi.org/10.1108/IJRDM-08-2016-0144

Bamforth, J., \& Geursen, G, M. (2017). Categorising the money management behavior of young consumers.

Berraies, S., Ben Yahia, K., \& Hannachi, M. (2017). Identifying the effects of perceived values of mobile banking applications on customers: Comparative study between baby boomers, generation X and generation Y. International Journal of Bank Marketing, 35(6), 10181038. https://doi.org/10.1108/IJBM-09-2016-0137

Chao, C. M. (2019). Factors determining the behavioral intention to use mobile learning: An application and extension of the UTAUT model. Frontiers in Psychology, 10(JULY), 115. https://doi.org/10.3389/fpsyg.2019.01652

Databoks. (2017). Pengguna Internet Berdasarkan Kelompok Usia. diakses pada 20 Februari 2020 dari https://katadata.co.id/datapublish/2018/0223/usia-produktif-mendominasi- 
pengguna-internet

Detik. (2019). Disorot Sri Mulyani, GoPay \& OVO Bisa Dipakai Bayar dari A Samapi Z. $\begin{array}{lllll}\text { Diakses } & \text { pada } & 2 & \text { April } & 2020\end{array}$ https://finance.detik.com/moneter/d-4425155/disorot-sri-mulyani-gopay--ovo-bisadipakai-bayar-dari-a-sampai-z

Detik. (2019). GoPay \& OVO Bisa Bantu Perbaiki Pengelolaan Anggaran, Bu Sri Mulyani?. Diakses pada 2 April 2020 dari https://finance.detik.com/moneter/d-4426350/gopay-ovo-bisa-bantu-perbaiki-pengelolaan-anggaran-bu-sri-mulyani

Fauzi, A., Widodo, T., \& Djatmiko, T. (2018 Pengaruh Behavioral Intention Terhadap Use Behavior Pada Penggunaan Aplikasi Transportasi Online (Studi Kasus Pada Pengguna GO-JEK dan GRAB di Kalangan Mahasiswa Telkom University.

Florenthal, B. (2019). Young consumers' motivational drivers of brand engagement behavior on social media sites: A synthesized U\&G and TAM framework. Journal of Research in Interactive Marketing, 13(3), 351-391. https://doi.org/10.1108/JRIM-05-2018-0064

Hastomo, A. D., \& Aras, M. (n.d.). INFLUENCE OF CASHLESS SOCIETY SOCIALIZATION TOWARD TRUST TRANSACTION CULTURE IN JAKARTA , INDONESIA. 1-13.

Joo, Y. J., Park, S., \& Shin, E. K. (2017). Students' expectation, satisfaction, and continuance intention to use digital textbooks. Computers in Human Behavior, 69, 83-90. https://doi.org/10.1016/j.chb.2016.12.025

Ketut, N., Rianadewi, N., Gede, D., Divayana, H., \& Pradnyana, I. A. (2019). ISSN 2252 - 9063 Kumpulan Artikel Mahasiswa Pendidikan Teknik Informatika ( KARMAPATI ) ANALISIS PENERIMAAN PENGGUNA SISTEM INFORMASI PERPUSTAKAAN DAN ARSIP DAERAH KABUPATEN BULELENG MENGGUNAKAN MODEL UNIFIED THEORY OF ACCEPTANCE AND USE OF TECHNOLOGY (U. 8, 394-403

Kompas. (2019). Penggunaan uang Elektronik Melonjak 77,6 Persen. https://www.kompas.com/2019/04/25/171509826/penggunaan-uang-elektronikmelonjak-776-persen

Kristianti, M. L., \& Pambudi, R. (2019) Analisis Pengaruh Persepsi Kemudahan, persepsi Kemanfaatan, Persepsi Tingkat Keamanan, dan Fitur Layanan Terhadap Penggunaan Mobile Banking Pada Mahasiswa di DKI Jakarta. Journal of Chemical Information and Modeling, 53(9), 1689-1699. https://doi.org/10.1017/CB09781107415324.004

Leon, S. (2018). Service mobile apps: a millennial generation perspective. Industrial Management and Data Systems, 118(9), 1837-1860. https://doi.org/10.1108/IMDS-102017-0479

Mandariza, A., Furkan, L. M., \& Mulyono, L. E. H. (2019). Faktor-Faktor Yang Mempengaruhi Persepsi Konsumen Pada Penggunaan Electronic Payment (Server Based). Jmm Unram Master of Management Journal, 8(4), 378-392. https://doi.org/10.29303/jmm.v8i4.467

Oentario, Y., Harianto, A. and Irawati, J. (2017). 'Pengaruh Usefulness, Ease of Use, Risk Terhadap Intention to Buy Online patisserie Melalui Consumer Attitude Berbasis Media Sosial Di Surabaya', Jurnal Manajemen Pemasaran, 11(1), pp. 26-31. doi: 10.9744/pemasaran.11.1.26-31.

Sihombing, R. J. (n.d.). Keabsahan electronic money di indonesia.

Sujarweni, V. (2014). Metodologi Penelitian: Lengkap, Praktis, dan Mudah Dipahami. Pustaka Baru Press.

Sugiyono. (2015). Metode penelitian \& pengembangan: Research and development untuk bidang pendidikan, manajemen, sosial, teknik. Bandung: Alfabet

Syahril, W. N., \& Rikumahu, B. (2018). Penggunaan Technology Acceptance Model (TAM) dalam Analisis Minat Perilaku Penggunaan E-Money pada Mahasiswa Universitas Telkom. Jurnal Mitra Manajemen ( JMM Online ), 3(2), 201-214. 
Pratami, S. W., (2018). Pengaruh Faktor Persepsi, Sosial-demografi Dan Keuangan Terhadap Preferensi Masyarakat Dalam Penggunaan Alat Pembayaran Non Tunai (Studi Kasus Pada Pengguna AMPK dan Uang Elektronik di Kota Malang).

Prakosa, Adhi., \& Wintaka, Dimas Jati. (2020). Analisis Faktor-Faktor yang Mempengaruhi minat Penggunaan Ulang E-Wallet Pada Generasi Milenial di Daerah Istimewa Yogyakarta.

Priyatno, D. (2014). SPSS 22 Pengolah Data Terpraktis. CV Andi Offset.

Riduwan \& Akdon. (2010). Rumus dan Data dalam Analisis Data Statistika. Bandung: Alfabeta.

Tweneboah-Koduah, E. Y., Adams, M., \& Acheampong, G. (2019). The role of theories in social marketing in predicting physical activity behavior among the youth. Journal of Social Marketing, 9(4), 398-417. https://doi.org/10.1108/JSOCM-01-2018-0005

Venkatesh, Viswanath, et al. (2003). User acceptance of information technology: Toward a unified view. MIS Quarterly: Management Information Systems, 27(3), 425-478. https://doi.org/10.2307/30036540

Widhiarso, Wahyu. 2019. "Prosedur Analisis Regresi Dengan Variabel Dummy." : 1-7. http://widhiarso.staff.ugm.ac.id/files/widhiarso_2010__prosedur_analisis_regresi_dengan_variabel_dummy.pdf.

Widyanto, Hanif Adinugroho, Kusumawardani, Kunthi Afrilinda, \& Septyawanda, Amreyzal. 2020. Encouraging Behavioral Intention To Use Mobile Payment: An Extension Of Utaut2. Jurnal Muara Ilmu Ekonomi dan Bisnis. 4 (1), 87-97.

Yani, E., Lestari, A. F., Amalia, H., \& Puspita, A. (2018). Pengaruh Internet Banking Terhadap Minat Nasabah Dalam Bertransaksi Dengan Technology Acceptance Model. 5(1), 34-42. 